\title{
LA IMAGEN COMO PRETEXTO. \\ LA NARRATIVA DE PADURA ENTRE LA POLÍTICA Y LA ESTÉTICA
}

POR

Ana María Amar SÁnchez

University of California-Irvine

Las relaciones entre estética y política han vertebrado gran parte de la reflexión teórica y crítica sobre el arte a lo largo del siglo XX -basta pensar en los debates sostenidos por la escuela de Frankfurt y las polémicas que han involucrado a las vanguardias-. En los comienzos del nuevo siglo asistimos a un resurgir de estas discusiones desde nuevas perspectivas lo que supone también enfocarse en ciertas formas narrativas en las que el nexo entre lo estético y lo político parece acentuarse notablemente. Si como afirma Rancière, "no hay ningún conflicto entre la pureza del arte y su politización" (Sobre políticas 27) puesto que "un arte crítico es un arte que sabe que su efecto político pasa por la distancia estética" ("Las paradojas" 84), es posible sostener que la literatura y la política se encuentran en un territorio común que es el de la estética. El arte ensaya entonces, ya sea en sus formas más explícitas o más elusivas, una particular configuración de estas relaciones. La cuestión será cómo diseña esas configuraciones, qué tipo de soluciones encuentra al intento de fusionar lo político en una forma estética específica. Donoso Macaya, en su ensayo "Estética, política y el posible territorio de la ficción en 2666 de Roberto Bolaño", sostiene, siguiendo también a Rancière, que "tanto el arte como la política producen distintas formas de ordenamiento y distribución, y es en ese sentido que ambos comparten una estética" (126). Lo político en el arte se vincula entonces a una articulación interna a la obra; desde esta óptica, y refiriéndose a Bolaño, "el compromiso político significa poder pensar la posibilidad misma de la política dentro de la ficción [...] se trata en definitiva de un compromiso estético" (129, énfasis de la autora).

Posiblemente sea la narrativa de Leonardo Padura una de las que suscita en el presente más interés -incluso inquietud y discrepancias- en la crítica; se diría que lo político es insoslayable en ella y, quizá por eso, la tensión entre ambos campos -estético y político- resulta problemática y ha ido generando diversas controversias. Justamente, porque es en verdad imposible dejar de lado en su obra las referencias externas explícitas en el plano del enunciado, es que importa ver cómo lo político se 
dispone, se configura en el decir de Rancière, en la ficción; es decir, qué articulación interna organiza esa fusión de planos heterogéneos.

En un trabajo anterior ("El arte de la política") analicé los vínculos entre su novela El hombre que amaba los perros (2009) con La segunda muerte de Ramón Mercader (1969) de Jorge Semprún y con la sección "La muerte de Trotsky referida por varios escritores cubanos, años después - o antes" perteneciente a Tres tristes tigres (1965) de Cabrera Infante. Vínculos referidos al aspecto político, pero en los que juega un papel fundamental lo estético, el compartir, a pesar de las diferencias, diversas estrategias narrativas similares. ${ }^{1}$ También Claudia Hammerschmidt examina en su artículo "La escritura como marca y máscara del significante ausente: Leonardo Padura y la visible ausencia de Guillermo Cabrera Infante" (2014) los nexos con este último autor: "Es obvio que El hombre que amaba los perros continúa el juego empezado en Tres tristes tigres, prolongando así la cadena de versiones sobre el asesinato de Trotsky por autores cubanos -años antes o después de la muerte de Cabrera Infante" (371-72). La autora considera que la escritura de Padura opera constantes tranformaciones de otros textos en el suyo y de sus propios textos "en palimpsestos que hacen traslucir y reescribir la tradición literaria" $(361){ }^{2}$

En suma, la novela de Padura se proyecta atendiendo a diversas estéticas y autores - de fuera y de adentro de la isla-; por ese motivo su literatura, conformada en la fusión de ambos campos, hace imposible excluir lo político, pero tampoco los procedimientos estéticos que dan forma, organizan y producen el sentido político. En mi ensayo consideraba que en El hombre que amaba los perros un punto clave de cruce entre esos campos se encontraba en la figura de un sujeto narrador complejo, ambiguo, que remite a diversas voces de enunciación, espacio de cruce entre ficción y referencialidad, entre el "adentro" y el "afuera" de la historia.

Cabe preguntarse cómo funciona este nexo, y a través de qué elementos, en otros textos del autor. Creo que poco se ha atendido a la cada vez más evidente conexión con lo visual en algunos de sus relatos; me refiero no a la reproducción de imágenes en

\footnotetext{
Asimismo, su narrativa policial -que ha sido la que más interés suscitó en la crítica, en especial $L a$ neblina del ayer- no sólo abre múltiples contactos con el género en América Latina y España, sino que se incorpora a la tradición más politizada de la literatura detectivesca. Allí también se entrecruzan proyectos estéticos y políticos de diversos modos, a la vez que despliega una cantidad de nexos con formas de la cultura popular, como el bolero y el cine.

2 Hammerschmidt analiza, además de las conexiones a propósito de Trotsky, "los ecos" de "Ella cantaba boleros" en La neblina del ayer; se enfoca en las estrategias con las que recupera un autor negado por la censura y define la técnica usada por Padura como la de "negar la negación". De este modo, sus textos pueden leerse como máscaras que muestran lo que parecen querer ocultar: "borran su centro al estilo de Cabrera Infante y lo circunscriben en la omisión misma" (364). Al reproducir sus mecanismos de ocultamiento, Padura continúa las técnicas narrativas de Cabrera Infante e instala al autor exiliado como centro de al menos dos de sus novelas.
}

$111 \frac{\text { Revista Iberoamericana, Vol. LXXXV, Núm. 269, Octubre-Diciembre 2019, } 1189-1204}{\text { ISSN 2154-4794 (Electrónico) }}$ 
su narrativa, sino a la presencia de la pintura en la forma de la descripción de cuadros que actúan como disparadores esenciales del relato y organizadores de la trama. Este trabajo se enfoca en el cuento "La puerta de Alcalá" de 1991 y en las novelas Paisaje de otoño de 1998 y Herejes, publicada en el 2013. Sin duda, podría afirmarse que la importancia de la pintura ha ido in crescendo de Paisaje de otoño a Herejes; sin embargo, ya juega un papel fundamental en "La puerta de Alcalá". ¿Cuál es la función de esta insistencia en la descripción de ciertos cuadros? ¿Y cuál es la razón de la compleja trama que los personajes tejen alrededor de ellos?

\title{
IMAGEN-ESPEJO: REFLEJO E INVERSIÓN DE LA REVOLUCIÓN CUBANA
}

Gracias a esa relación con lo pictórico, el fuerte vínculo que El hombre que amaba los perros había establecido con La segunda muerte de Ramón Mercader en términos de historia y procedimientos parece extenderse a otros relatos de Padura. En efecto, Semprún es uno de los escritores en cuya obra pueden encontrarse más menciones y referencias a cuadros: en La segunda muerte de Ramón Mercader, Vista de Delf ocupa un lugar central. La tela de Vermeer se halla en el Museo Mauritshuis de La Haya; allí comienza la novela con una escena en la que el protagonista contempla un paisaje: "Él se encontraría de este lado de la gris extensión de agua, donde algún claro del cielo ponía reflejos cambiantes, pero que sin embargo no parecía, curiosamente, reflejar la luz velada de un sol que se podría suponer suspendido en alguna parte [...]" (Semprún 13).

La descripción continúa durante casi tres páginas y sólo entonces el lector se da cuenta que no se trata de un paisaje real, sino del cuadro de Vermeer; luego, el personaje "abandona la sala [...] y se inmoviliza ante El Jilguero de Carel Fabritius" (Semprún 15). El pasaje por la pintura holandesa -las descripciones y reflexiones sobre ellacontinúa así a lo largo de todo el capítulo (y de hecho se retoma en distintos momentos del relato). Padura evoca claramente esta novela en la tercera parte de Herejes, allí el ex detective Conde se encuentra en una casa de La Habana con

\begin{abstract}
un entorno donde resaltaba la falsedad rotunda de unas magníficas reproducciones colgadas de las paredes; la inconfundible Vista de Delft, de Vermeer, el conocido interior de una iglesia de Emanuel de Witte, y un paisaje invernal, con molino incluido, cuyo autor original no pudo establecer, aunque sin duda era holandés como los otros dos maestros. ¿Por qué insistían en salirle al paso, en cualquier parte, los cabrones pintores holandeses? (366)
\end{abstract}

Poco después, en un regreso a la misma casa, su vista "se concentró en las magníficas reproducciones de pintores holandeses colgadas en la sala. Vermeer de Delft, De Witte y, acercándose al paisaje, leyó la firma copiada: Jacob van Ruysdael" (417). Es interesante que al observar estas copias, Conde no pueda evitar recordar "la

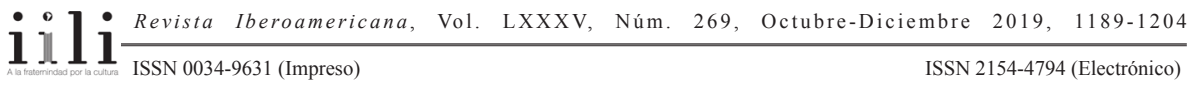


historia del Matisse falso que parecía auténtico y que había provocado las ambiciones de varias personas" (418) y un asterisco al pie de página nos remita a la edición de Paisaje de otoño. Está claro que Herejes establece nítidamente el vínculo con la novela de Semprún a través de la pintura, a la vez que también mantiene un nexo constante con los textos anteriores de Padura. Sin embargo, El hombre que amaba a los perros, el más cercano a Semprún en términos temáticos y formales, omite esta relación con lo pictórico para retomarla -en una especie de juego cruzado- como una cita desplazada y con más fuerza en Herejes.

¿Cómo podemos leer esta presencia dominante de lo pictórico? En el caso de Semprún, la crítica ha encontrado rasgos biográficos del autor ligados a su historia política: la niñez, la conciencia del exilio, del desarraigo, la evocación de la ciudad en la que se ha vivido en la infancia. Françoise Nicoladzé señala que "el inicio de $L a$ segunda muerte de Ramón Mercader sugiere una correspondencia entre la Vista de Delft de Vermeer y la larga espera del regreso a Madrid" (148). La ciudad de Vermeer ocupará en el imaginario el lugar de la ciudad de su infancia: una ciudad lejana a la que desea volver. Para Fernández Pérez el paisaje del cuadro cobra así una doble dimensión, complementaria y contradictoria: es al mismo tiempo el paraíso perdido y la imposible patria que el exiliado contempla desde la orilla y que presagia un futuro incierto. A su vez, Valeriano Bozal señala que este cuadro "no destaca por la profundidad de la perspectiva o por la distancia que en él alcanza la vista sino por la presencia de Delft, su materialidad fuera del tiempo, tan alejada de lo descriptivo y pintoresco" (179). La ciudad es a la vez próxima y lejana, aislada en un tiempo suspendido que no es el nuestro. Esa ciudad de Delft, deseada pero inalcanzable, es una metáfora de Madrid, ciudad de la que Semprún fue expulsado por la guerra y a la que espera volver algún día. Como vemos, la lectura política se impone en todos los casos para explicar la importancia del paisaje de Vermeer en una novela en que es dominante la reflexión sobre el fracaso de las ilusiones centradas en el Partido Comunista español.

El cuento de Padura "La puerta de Alcalá" también es un relato acerca del desarraigo, en torno a la disyuntiva de irse o quedarse en la isla, decisiones que siempre redundan en pérdida y dolor para todos. El relato toca nudos característicos de sus novelas posteriores, el exilio, el desgarro de las separaciones, la experiencia en Angola y la censura del trabajo literario del personaje, pero en este caso en la organización de la trama se introduce Velázquez y un pequeño cuadro que se encuentra en el Prado, casi escondido en una sala donde brillan muchos de sus grandes lienzos. Mauricio, el protagonista, compra en una librería de viejo de Luanda-donde se encuentra en plena guerra de Angola como periodista "castigado"- un pequeño librito sobre Velázquez que funciona como un disparador de su imaginación y de su deseo. La vida del pintor, uno de sus dípticos y María Fernanda, la anterior dueña del libro, que ha dejado allí algunos datos que se convierten en huellas, son signos de "ese otro espacio", esa

$111 \frac{\text { Revista Iberoamericana, Vol. LXXXV, Núm. 269, Octubre-Diciembre 2019, 1189-1204 }}{\text { ISSN 2154-4794 (Electrónico) }}$ 
otra vida opuesta en todo a su realidad en Africa: si en la página 13 siente que "el mundo es una mierda", en la 16 pensará que "para Velázquez, al menos, la vida no fue una mierda". La obsesión con el cuadro "La tarde" que junto con "El mediodía" conforman el díptico llamado "Vista del jardín de la villa Médicis" lo llevará a desear desesperadamente hacer a su regreso una escala en Madrid, conocer el Prado y ver ese cuadro. Como suele ocurrir con la materia de los sueños, el deseo no podrá cumplirse; a cambio, el protagonista se encontrará con un amigo exiliado y se iniciará un largo debate sobre el destierro y las ilusiones perdidas de ambos. El cuento queda así dividido en dos secciones: la primera, en Angola, donde el encuentro con ese librito abrirá un mundo totalmente opuesto al que vive, termina con su llegada a Madrid el día en que el Prado está cerrado. La segunda consiste en esa conversación con el amigo exilado en EE.UU., un balance sobre las pérdidas irreversibles tanto de unos como de otros, ya sea que se esté en Luanda, Madrid, Nueva Jersey o La Habana.

El deseo de Mauricio se había disparado a partir del anuncio de una exposición encontrado en un periódico poco antes de su partida: “TODO VELÁZQUEZ”, en el que luego se informaba que "entre el 23 de enero y el 30 de marzo estaría abierta en el museo de El Prado la llamada exposición del siglo" (12). ${ }^{3}$ El aviso hace renacer la fascinación que había despertado el librito comprado tiempo atrás donde se reproduce "La tarde", la primera pintura en la que Velázquez - hay que recordarlo y lo destaca el narrador- abandona los espacio cerrados y pinta al aire libre al óleo con lo que se adelanta en dos siglos al impresionismo: la descripción de los árboles "de hojas difuminadas sobre los arcos de una galería renacentista, y la luz imprecisa y tibia [...] que borraba los contornos de los dos personajes" (19) concluye con

Aquella tarde magnífica en el jardín de los Médicis daba deseos de vivir y trasmitía el júbilo que debió sentir el artista mientras dejaba correr, libre y sin compromisos con reyes más o menos comprensivos y generosos, sus mejores pinceladas de hombre apacible. (19)

El texto se desplaza del espacio representado en la tela al mismo Velázquez del que poco antes se dice

Su relación con el rey sólo terminará con la muerte del pintor y, si alguna vez esta condición disminuyó su libertad, en cambio, le ofreció la posibilidad de una vida tranquila, libre de preocupaciones financieras y, por otra parte, el soberano nunca lo oprimió exageradamente con obligaciones ni condiciones. (17)

\footnotetext{
"El mundo es una mierda, se dijo, yo cagándome en Angola y la gente en Madrid preparándose para ver, justamente, una irrepetible exposición de Diego Velázquez” (13).
}

$111 \frac{\text { Revista Iberoamericana, Vol. LXXXV, Núm. 269, Octubre-Diciembre 2019, } 1189-1204}{\text { ISSN 2154-4794 (Electrónico) }}$ 
Es fácil observar que "el mundo Velázquez" (telas y vida) es la contracara de lo vivido por el personaje en Angola y de sus dificultades con el gobierno cubano; la existencia feliz, "al servicio de soberanos comprensivos y generosos" (17) que el texto atribuye a Velázquez es la antítesis de la experiencia vital de Mauricio. La suave tarde en el jardín romano funciona como la ciudad de Delf en la novela de Semprún; es decir, la pintura es una ventana a un mundo perdido o deseado y a una vida imaginaria y diferente de la que ha tocado. La paz, el apoyo del mecenas, la libertad creativa tienen su negativo en la guerra de Angola y las restricciones que sufre como periodista. La tela parece representar una alternativa de felicidad, belleza y libertad que el protagonista anhela, lo mismo que la vida de Velázquez, artista sin conflictos con el poder, resulta la contrapartida de la suya. ${ }^{4}$ Por eso cuando Mauricio proyecta escribir la historia de "un desencuentro a través de Europa y África de dos personas que en realidad habían nacido para fundirse" (36), piensa que "la prosa tendría los colores de Velázquez y el físico de María Fernanda sería el de La Venus del espejo" (36). Sin embargo, rápidamente comprende que nunca podrá escribir esa historia que lo desborda y admira "la valentía de Velázquez, y su sentido de la libertad artística que ningún rey le pudo arrebatar del todo"(38). La plenitud que imagina en la escena representada y en la vida de Velázquez convierte al librito en un talismán, en el objeto protector que garantiza alguna forma de retorno al hogar: ésa es la razón por la que en el intercambio de recuerdos Mauricio se lo regala al amigo que vuelve a los EE.UU. Ambos asumen distintas formas del fracaso y saben que en sus regresos -ya sea a EE.UU. o a Cuba- no conseguirán ser felices; por eso en el final, luego del largo debate en torno al exilio, Mauricio entrega el libro diciendo: "es bueno pensar que alguna vez vamos a visitar otra vez el jardín de los Médicis" (45).

La luminosa tarde en el jardín romano es el espejo invertido de lo real como en la novela Paisaje de otoño lo es el supuesto cuadro de Matisse del mismo nombre. Allí el detective Conde investiga el asesinato de Miguel Forcade, un miembro del gobierno que desertó en 1978 y acaba de volver a Cuba para, según dice, visitar a su padre enfermo. Conde inicia la investigación, que promete sacar a la luz una oscura trama de corrupción, mientras espera el ciclón Félix y mira por la ventana las señales de su llegada. Esa mirada se reitera a lo largo de la novela y lo que ve dista mucho de parecerse al paisaje del falso Matisse. El narrador señala:

El Conde abandonó su butaca y miró por la ventana: las rachas de aire empezaban a peinar las copas de los árboles, como presagio de males mayores por venir [...] Aquél era un paisaje de otoño distinto al imaginado por Matisse, en la racional y mesurada

4 Dice Mauricio a propósito del díptico Vista del jardín de los Médicis: "esa es la felicidad más completa que conozco. Creo que si un día yo pudiera escribir algo así, o sentirme como si estuviera allí, creo que sería feliz" (41). 
Europa: el signo otoñal del trópico nada tenía que ver con hojas caídas por el cambio preciso de estación ni con luces filtradas entre nubes altas. Aquellos árboles que veía el Conde practicaban la avaricia de jamás soltar sus hojas [...] y la luz del país sólo tenía dos dimensiones reales: o el azul intenso del cielo despejado [...] o el gris profundo de la tormenta [...] Era una naturaleza que periódicamente [...] advertía de sus infinitas posibilidades de venganza. (218, énfasis mío) ${ }^{5}$

Lo real está muy lejos de la representación pictórica: la descripción de la tela, como en todos los textos de Padura, opone dos mundos y es esencial para entender su función en el relato: "sobre el lienzo se extendía una calle [...] bordeada de árboles que eran acariciados por un viento insistente, capaz de inclinar sus copas, fundiendo sus follajes en una paleta rotunda de verdes otoñales y ocres vespertinos, de los que [...] brotaba una luz propia" (57). Esta descripción se contrapone con el paisaje de la ciudad esperando el ciclón y se completa muchas páginas después con la pregunta: “¿Es un Matisse bastante impresionista, en el que se ven unos árboles movidos por el viento en una calle bastante desierta, $\mathrm{y}$ al fondo hay una pequeña mancha amarilla que puede ser un perro?" (106). Justamente comprobar la ausencia de ese perro amarillo presente en el original, permite delatar la falsificación y, en consecuencia, la corrupción de los dirigentes políticos.

Esta novela evoca, el cuento anterior gracias a la fuerte presencia del juego entre ilusión o deseo vs. realidad: la imagen de paz, belleza y suave brisa contrasta con la de una ciudad en decadencia y en espera del ciclón que en las últimas páginas mostrará su capacidad destructiva. Al mismo tiempo hay que recordar que la dedicatoria a Hammett "por El halcón maltés" guía en parte nuestra lectura y genera una cadena de asociaciones que pasa por el supuesto cuadro de Matisse y termina en el Buda de oro escondido -claro desplazamiento de la figura del halcón maltés-. ${ }^{6}$ Como éste, la tela y el Buda son el producto de una ilusión, de un sueño, pero también son el resultado de la avaricia y las manipulaciones de funcionarios corruptos (es bueno no olvidar que es en esta novela que Conde abandona, hastiado, la policía): "la sucesión de engaños de todas las especies que había venido a dar en sus manos resultaba fascinante. Traiciones,

5 El texto insiste en la mirada de Conde a través de la ventana: "Desde su pequeña oficina en la Central, el Conde volvió a observar el paisaje casi inamovible que se le ofrecía desde la ventana” (100); “desde la ventana se veía un cielo ahora agrisado, con una amenaza tangible de lluvia, aunque las copas de los árboles se mantenían inmóviles" (134). Del mismo modo, el paisaje urbano es la antítesis de la imagen pictórica: "gentes que al salir a la calle siempre debían ver ese mismo panorama oscuro y desolador, tan alejado de paisajes posibles de Matisse, de Cézanne[...]" (117).

6 En la novela de Hammett, el halcón maltés, una talla antigua con una larga historia y supuestamente de gran valor, resulta una escultura de plomo. El Buda tiene una historia de robos y extravíos muy semejante, pero es de oro y es el cuadro el que resulta falso. Paisaje de otoño construye un juego de citas -y así lo señala-duplicaciones e inversiones con El halcón maltés y, a la vez, lleva el nombre del cuadro de Matisse que también ha sido duplicado y del que se conoce solamente la versión falsa.

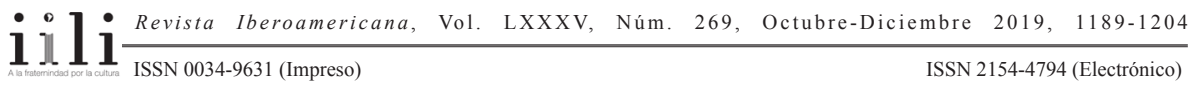


fraudes, persecuciones, mentiras e imposturas de todo tipo[...]" (200). En verdad, la investigación que termina en el Buda atraviesa un entramado de pinturas dudosas: falsas, auténticas, robadas, desaparecidas. Entramado que se conecta, por otra parte, con la siguiente novela, Herejes, en la que se expande el eje "lo falso vs. lo auténtico" que sostiene en el nivel de la trama una cuestión clave para la política del texto: el proceso de descomposición del sistema en manos de funcionarios corruptos que han traicionado los ideales revolucionarios. ${ }^{7}$

Ilusión -refugio utópico por su belleza- y mentira, a la vez, la falsa tela de Matisse expone en la ausencia de la pequeña mancha amarilla que la diferencia del cuadro auténtico y en la oscura trayectoria de su venta fraudulenta la pérdida, en los dirigentes, de los valores que postulaba la Revolución. Por eso la historia que quiere escribir Conde es la "de la frustración y el engaño, del desencanto y la inutilidad, del dolor que produce el descubrimiento de haber trastocado todos los caminos" (26). El engaño en todos los sentidos, políticos y estéticos, se condensa en el cuadro que primero le parece una "magnífica reproducción de una posible obra de Cézanne" (57) y luego pasa por ser un Matisse original para terminar siendo "un chiste macabro" (130).

Justamente, las preguntas que se abren ante ese cuadro acerca de cómo ha llegado hasta allí y si es auténtico o no, resultan esenciales en la última novela de Padura, Herejes, en la que el largo y dudoso camino de una tela de Rembrandt será el índice de un cierto estado de cosas en la isla. La fusión entre política y arte abrirá múltiples alternativas de sentido: si la tela permite -como en el primer relato considerado- el pasaje a otro mundo que se confronta con el que se vive; si su historia en la isla denuncia la pérdida de valores de funcionarios corruptos involucrados en su robo o en su venta y capaces de llegar a la infamia para ganar dinero como en Paisaje de otoño, aquí se agrega una nueva alternativa. La figura del hereje ya no es sólo la contracara de lo real, sino que refleja, como si fuera un espejo, la condición de varios personajes, también "herejes" en su defensa de la libertad de pensamiento y de las diferencias. ${ }^{8}$

En Herejes el cuadro de Rembrandt "representa" (es decir, trae a escena, hace presente) a un hereje: un judío que se parece a Jesús, lo personifica y además es pintor;

\footnotetext{
7 El tópico del tráfico de obras de arte que debían pasar al Estado y acaban en casas de funcionarios o son objetos de ventas ilícitas se inicia en esta novela y se desarrollará en Herejes; obras que no se sabe dónde están, si fueron robadas o se las ha sacado del país secretamente funcionan como signos de la degradación de la clase dirigente: "la verdad es que nunca se supo muy bien dónde había ido a parar el Matisse" (110); "hay otras tres piezas de las que nunca se ha vuelto a saber y que hoy deben costar varios millones" (112); "la larga pista de un Paisaje de otoño falso que existía porque también existió uno verdadero cuyo destino aún se desconocía" (136).

8 El texto recoge varias acepciones de la palabra según el Diccionario de la Real Academia, entre ellas: "persona que disiente o se aparta de la línea oficial de opinión seguida por una institución, una organización, una academia, etc", pero destaca en negrita "Cuba. Dicho de una situación: [Estar hereje] Estar muy difícil, especialmente en el aspecto político o económico" (15, la bastardilla es del autor).
}

$111 \frac{\text { Revista Iberoamericana, Vol. LXXXV, Núm. 269, Octubre-Diciembre 2019, 1189-1204 }}{\text { ISSN 2154-4794 (Electrónico) }}$ 
múltiple herejía que se expande en los diversos herejes protagonistas de las otras historias narradas. ${ }^{9}$ Como en el caso de Velázquez, el mismo Rembrandt es la culminación de esta cadena asociativa, su punto de condensación; el relato pone en la voz del pintor un extenso discurso libertario:

Para un artista todos los compromisos son un lastre; con su Iglesia, con un grupo político, hasta con su país. Reducen tu espacio de libertad y sin libertad no hay arte [...] siempre habrá iluminados dispuestos a apropiarse de la verdad y a tratar de imponerle esa verdad a los demás [...] siempre hay otros hombres que [...] llegan al extremo de pensar que su modo es el único correcto [...]Y ese resulta ser el fin de la libertad. (235)

El discurso, en gran medida anacrónico si lo pensamos enunciado por el pintor en pleno siglo XVII, que en su comienzo parece referirse estrictamente al arte se abre a otras posibles significaciones y apunta a la lucha por defender, más allá del destino o las creencias dadas, el pensamiento propio y la libertad de elección; es decir, la "voz" del pintor se hace eco - otra vez representa- de los distintos herejes - sus luchas y sus resistencias- que pueblan las tres historias de la novela.

Así como Herejes expande las relaciones con la pintura que se planteaban en los relatos previos, también explicita sus vínculos con ellos a manera de un balance o resumen de la propia producción de Padura en un punto quizá culminante de esta relación con la imagen pictórica. La mención de episodios en el cuerpo del texto y en notas al pie, es continua y en especial se insiste en el recuerdo de la investigación de Paisaje de otoño. ${ }^{10} \mathrm{El}$ ofrecimiento para hacerse cargo de buscar la pista del Rembrandt perdido que abre el relato lo remite de inmediato al caso anterior:

¿Un Rembrandt, en Cuba? Años ha, cuando era policía, la existencia de un Matisse lo había llevado a meterse en una dolorosa historia de pasión y odio. Y el Matisse había resultado ser más falso que el juramento de una puta...o de un policía. Pero la mención de un posible cuadro del maestro holandés era algo demasiado magnético. (33-34)

9 La historia del origen de esa pintura de Rembrandt, del joven judío y alumno del maestro que sirve de modelo, del pasaje a la familia del protagonista, es no sólo el eje conductor de la trama, sino que entreteje y relaciona las historias unidas por elementos comunes de todos los personajes vinculados con el cuadro: tanto Daniel, el heredero de la tela que se salvó del nazismo, como el modelo que en 1645 posó para ella como la muchacha emo, gracias a la cual se establecen los nexos y la oscura trayectoria del cuadro, son "herejes", disidentes, religiosos, políticos, sociales, rebeldes a la sujeción de cualquier sistema impuesto.

${ }_{10}$ Conde recuerda la "maravillosa biblioteca descubierta" en La neblina del ayer (384), el romance iniciado en Pasado perfecto (146), a su amigo Iván, el protagonista de El hombre que amaba los perros (493) y la investigación de Máscaras (460).

$111 \frac{\text { Revista Iberoamericana, Vol. LXXXV, Núm. 269, Octubre-Diciembre 2019, } 1189-1204}{\text { ISSN 0034-9631 (Impreso) }}$ 
Ya casi al final de la investigación y cerrando la escena -mencionada al principio de este ensayo- frente a las copias de cuadros holandeses, Conde no puede evitar recordar "la historia del Matisse falso que parecía auténtico y que había provocado las ambiciones de varias personas. Y el destino cubano, todavía incierto, del retrato del joven judío realizado por Rembrandt [...]" (418). Ambos momentos conectan estrechamente las dos investigaciones en las que los cuadros europeos son el centro de complejas tramas de corrupción política. A tal punto se encadenan ambos que se reitera una escena casi idéntica a la de Paisaje de otoño en la que Conde mira por la ventana la ciudad:

Asomado a la ventana encendió un cigarrillo y se dedicó a observar el panorama [...] Como años atrás tuvo un vislumbre del mar [...] Aunque el cuadro que se podía contemplar desde la ventana apenas había cambiado, Conde sabía que se trataba de una percepción engañosa. Todo se movía. (451, énfasis mío)

Si los cuadros funcionan como ventanas a "otro mundo" que se abren al deseo, a la ilusión, a identidades, espacios, tiempos y vidas diferentes, las ventanas son cuadros que devuelven a la realidad. ${ }^{11}$ Sin embargo, ambos -ventana y cuadro- se reflejan entre sí y son variables de una misma lectura política; una lleva al otro y estableciendo un vaso comunicante que remite del ámbito de la imaginación que genera la imagen pictórica frente al mundo real de La Habana vislumbrada como un reflejo invertido, pero también como una continuidad en el caso de la figura del hereje "reencarnado" en los protagonistas de la última novela.

Sin duda, en Padura, la imagen pictórica es "organizadora" de la significación que va en múltiples direcciones: no sólo es el hilo que entreteje las historias, sino que permite el "equilibrio" entre arte y política. Desde este punto de vista, es lógico que abunden las descripciones de telas y se definan personajes o situaciones por la posesión o no de auténticas pinturas cubanas u holandesas. El detective Conde de modo reiterado observa las obras de arte colgadas en las casas a las que ingresa siguiendo pistas. Se mencionó al comienzo de este trabajo su "evaluación" de una colección de reproducciones holandesas, pero también hacia el final de la novela encuentra en

11 Es interesante la aparente falta de función de la detallada descripción del famoso cuadro "La ronda" de Rembrandt en esta novela; sin embargo, es el resultado de la mirada del personaje Elías Ambrosius, el joven judío aprendiz del pintor, que queda extasiado al verlo y se "sumerge" en él al punto de que el bedel "apenas pudo sacarlo del embrujo en el cual Elías Ambrosius había caído" (210). También para él -el hereje que representa a Jesús en la tela objeto central de la trama- el cuadro es una ventana a un mundo que entrevee como lo deseable (ser pintor, vivir otra vida, etc). De algún modo la escena representa la función más evidente que tiene la pintura en las novelas de Padura, la de catalizar el deseo de otra vida y el olvido de la real. 
otra casa originales muy valiosos de artistas cubanos. ${ }^{12}$ No parece casual que sea esta casa, de una riqueza ostentosa, cubierta de obras de arte, el hogar de un muchacho que termina en la cárcel implicado en un asesinato. La corrupción de los padres acaba en la última parte de la novela en el camino sin rumbo y hacia la muerte de los hijos.

\section{LA IMAGEN: ENTRE LA ESTÉTICA Y LA VIOLENCIA}

Resulta interesante, sobre todo con referencia a la última novela de Padura, establecer brevemente algunas conexiones con el Tríptico de la infamia de Pablo Montoya publicada en 2014 -es decir un año después de Herejes- donde el trabajo sobre la imagen y su función toman otro camino. Sin duda se trata también de un texto muy ligado a lo político en el que sus tres secciones tienen como protagonistas a dos pintores y un grabador europeos, ninguno de ellos muy conocido por el público en la actualidad: Jacques Le Moyne (1533-1588), François Dubois (1529-1594) y Théodore de Bry (1528-1598). Sus vidas se encuentran en el cruce de las luchas -y la violencia-religiosas, políticas, sociales con las preocupaciones estéticas. En la primera parte, Le Moyne viaja a América con una expedición francesa que intenta establecer una colonia protestante en lo que hoy es la Florida. Contratado para dejar constancia a través de su pintura de ese mundo nuevo y de los hechos que allí ocurren, su experiencia fundamental se da en el descubrimiento de que "el cuerpo para los indios [...] era como una gran tela [...] el cuerpo se manifestaba [con los tatuajes] como el lugar de todas las representaciones" (44). A la inversa del resto de la expedición, inmersa en el proyecto "civilizatorio", por una parte, y en la lucha contra los españoles por el control territorial y religioso, por otra, Le Moyne intenta una relación igualitaria incorporando el mundo del color y la imagen de la cultura aborigen. De ahí que el pintor llene sus cuadernos con "diseños geométricos donde la espiral, el círculo, el cuadrado se abrazaban incesantemente" (71) y tenga la idea de pintar su cuerpo a pesar de que sabe que "jamás podría ser cabalmente un indígena. Pero volvería con una huella, no solo estampada en sus recuerdos, sino signada en el cuerpo" (76). Regresa, de hecho, con esa huella en la forma de una "pequeña lagartija [en su dedo] que Kututuka le había pintado. Significaba la amistad perdurable" (112). Aquí el color y la imagen adquieren una significación en sí mismos: Le Moyne corporiza la pintura, de algún modo se fusiona con el indígena Kututuka (es importante recordar que se pintan mutuamente diversos dibujos en la piel) y es sintomático que haga diseños abstractos, pues parece no necesitar ya de la representación figurativa en tanto que el cuerpo es el espacio

12 "En las paredes destellaban pinturas originales de los más cotizados pintores cubanos de los últimos cincuenta años. Un efebo desnudo y muy bien dotado de Servando Cabrera, una ciudad oscura de Milián, una mujer de ojos desorbitados de Portocarrero, una sirena yacente de Fabelo, una mujer descoyuntada de Pedro Pablo Oliva [...]" (434).

$111 \frac{\text { Revista Iberoamericana, Vol. LXXXV, Núm. 269, Octubre-Diciembre 2019, } 1189-1204}{\text { ISSN 0034-9631 (Impreso) }}$ 
donde cobra sentido ese encuentro. A diferencia de la destrucción y el fracaso en que termina la expedición, su vínculo con la cultura nativa deja una marca, un recuerdo que será recuperado en las siguientes secciones, especialmente en la última, donde De Bry establece contacto con Le Moyne y compra sus dibujos luego de su muerte.

A partir de esta conexión, la compleja red de correspondencias entre la imagen y las formas de la violencia - de la infamia- política y religiosa, tanto en Europa como en América, vertebra las otras dos secciones, unidas entre sí por una palabra clave: Bartolomé. La terrible matanza de hugonotes-de la que es víctima la familia de Duboisen la Noche de San Bartolomé se liga con la última parte en la que De Bry realiza los grabados para la edición ilustrada de la Brevísima relación de la destrucción de las Indias de Bartolomé de las Casas. El fanatismo religioso, la capacidad de destrucción, la crueldad, ejercidas tanto en América como en Europa, dan origen a formas de representación y reflexiones en torno a ellas muy actuales que, por momentos, y como en Padura, rozan el anacronismo. ${ }^{13}$ El sistema de "traducción" que produce el relato parece ejemplar del modo en que funciona la novela: la tela de Dubois, Masacre de San Bartolomé, es descripta en detalle por su propio autor y los diecisiete grabados de De Bry se despliegan en una minuciosa relación que, a su vez, duplica el texto de De las Casas. ${ }^{14}$ Este sistema de "traslación" va acompañado de constantes reflexiones acerca de su pertinencia y su función en tanto denuncia o lucha contra el olvido. Si el cuerpo pintado en la primera parte era ya en sí mismo un texto político plagado de sentido, los protagonistas de las otras secciones se enfrentan con el conocido dilema de la función política del arte y su modos de representación: describir las obras conlleva el debate sobre estas cuestiones. Frente a la insistencia para que pinte un cuadro que se refiera a la masacre, Dubois duda en la eficacia del arte como denuncia. Ya sus telas anteriores se caracterizaban por no mostrar nada, en ellas solo se percibía "el eco de sus figuras ausentes" (146), por lo tanto no cree en ningún tipo de representación directa ni en su utilidad y su discurso lo explicita:

13 Es bueno destacar que en la última parte se introduce un narrador que en varias ocasiones establece conexiones con el presente y se pregunta qué respondería De Bry si "le refiero algunos eventos de mi época, no para angustiarlo, sino más bien para consolarlo. Los campos de concentración, las hambrunas, el sida, las bombas atómicas, la manipulación genética, la industria nuclear [...] mi tiempo es quizá más pavoroso que el suyo" (269). Esta voz se interroga a propósito del último grabado en el final del relato: “¿por qué esta particular síntesis, esta notable condensación? ¿Será porque se narran las 'crudelísimas crueldades', la expresión es del genio literario de De las Casas, de una región que habría de corresponder más tarde al país harto de inequidad social que sigue siendo Colombia? La hipótesis es seductora" (299). De este modo el texto remite al lector a la continuidad de la violencia-y de la infamia- en su presente.

14 Es significativo que exista un proyecto, nunca realizado, de otro pintor, Étienne Delaune, de hacer un libro sobre la masacre de San Bartolomé acompañado de ilustraciones. A cambio de éste, De Bry ilustra el de Fray Bartolomé: una masacre por otra, una religión por otra, un continente por otro, pero el mismo horror.

$111 \frac{\text { Revista Iberoamericana, Vol. LXXXV, Núm. 269, Octubre-Diciembre 2019, } 1189-1204}{\text { ISSN 2154-4794 (Electrónico) }}$ 
El verdadero artista es siempre ajeno a esas contigencias. (167)

¿Podría la factura de un óleo curarme no solo de mis heridas aún no cerradas, sino de las laceraciones que padecen mis contemporáneos? (168)

¿Es posible fijarlo [el dolor] en una tabla o en un pedazo de tela? ¿Qué tiene que ver el color con el dolor? (180)

¿De qué manera lograr que con unos cuantos rasgos se exprese la dimensión de un mundo despiadado? [...] jamás es lo mismo una masacre que su representación. (185)

Sin embargo, realiza la tela que, por otra parte, generará la emoción de De Bry cuando la vea años después e influirá en sus propios grabados ${ }^{15}$ no parece casual que al verla enuncie una de las preocupaciones medulares de la novela:

De Bry trataba de establecer un lazo entre las muertes del mosaico que había pintado Dubois y las que lo asediaban desde el otro lado del océano. Era como si el mal entre los hombres tuviese el mismo semblante [...] el mismo desorden en el fondo calculado. (275)

Los autores Dubois y De Bry quedan así ligados por los mismos intereses políticos y estéticos que se expresan también en la descripción del cuadro del primero y de los grabados del segundo. Si bien Dubois había tomado la resolución de no pintar la masacre porque no encuentra sentido en repetirla en su tabla, su relato sobre las imágenes obtenidas dista de la repetición mimética, son el producto de una lucha en que términos como configurar, moldear, excluir, delinear, y trazar construyen un París y una matanza condensadores de un horror fácilmente desplazable a otro crimen, el realizado en América y marcado asimismo por el signo Bartolomé, signo que fusiona violencia, religión y política, pero que apunta también en ambos a cuestiones estéticas. En efecto, aunque De Bry afirma que ha tenido la intención de denunciar con sus grabados, es acosado por las mismas dudas que planteaba Dubois:

¿Qué significa pintar y qué significa ser asesinado? ¿Qué significa la muerte violenta y qué la representación de la muerte? [...] Creo que todo intento de reproducir lo pasado está de antemano condenado al fracaso [...] ¿Bastan diecisiete grabados para redimir la infamia que la violencia provoca? [...] No ignoro que solo he pintado la imagen de un exterminio. (278-79)

15 En la tercera parte se describe la reacción que produce el cuadro en Théodore de Bry: "Su corazón dio un vuelco [...] En la boca se instaló una sequedad advenediza. Un nudo compacto se le hizo en la garganta [...] La violencia, diseminada con calculada simetría en sus numerosas escenas, se le hundió en la mirada $[\ldots]$ " (274).

$111 \frac{\text { Revista Iberoamericana, Vol. LXXXV, Núm. 269, Octubre-Diciembre 2019, } 1189-1204}{\text { ISSN 0034-9631 (Impreso) }}$ 
A continuación de estas palabras se desarrolla el extenso capítulo titulado "El exterminio" en el que se describen los grabados, pintados para ilustrar lo que narra De las Casas. Este sistema de desplazamientos de la crónica a la imagen y a su descripción -escritura, ilustración y escritura que remiten, a su vez, a la tela de Dubois y a su explicación en la segunda parte de la novela- permite exponer los reparos en torno a las dificultades de representación que confluyen en el término Bartolomé, verdadero punto de encuentro de los procesos artísticos y la violencia comunes al relato de De las Casas, a los grabados de De Bry, a la tela de Dubois y a las descripciones del texto.

Asimismo, los grabados de De Bry cierran el círculo al remitir a la primera parte, no solo por su contacto con Le Moyne, como ya se dijo; De Bry, preocupado por el fracaso de todo intento de reproducción, busca, de modo paradójico, sus modelos en el imaginario europeo y "torna griegos y romanos a los nativos" (246). Es decir, éstos "son representados, en verdad, con los rasgos de la estética europea. Pero poseen los contornos de una alteridad extraña"(230). Hemos llegado al extremo opuesto del proyecto de Le Moyne quien pretendía confundirse con el mundo indígena y trataba literalmente de incorporar, absorber, corporizar sus colores y dibujos abstractos. Quizá esta distancia final de De Bry (quien nunca conoció América) expresa -y explica- la imposibilidad de la fusión, de un encuentro entre iguales que anhelaba el utópico Le Moyne; la violencia compendiada en el vocablo Bartolomé vale para ambos mundos, pero eso no significa que entre ellos pueda haber verdadera comprensión. ${ }^{16}$

Puede aceptarse que la imagen adquiere en Montoya otras significaciones; en la primera sección en particular, alcanza un espesor corporal, pero también en las siguientes actúa en la trama; la reflexión sobre el posible poder político de su condición estética conlleva una funcionalidad interna al relato que permite pensar a partir de ella la violencia, la guerra, la destrucción. La pintura nos acerca, nos hace presente, la infamia al mismo tiempo que analiza su propia capacidad de acción. A diferencia de lo que ocurre en los textos de Padura, la imagen no es un espejo - no refleja ni refractani es una ventana hacia la historia que se narra, un territorio que permite "estabilizar" el peso de lo político. En Montoya, la imagen es el núcleo mismo -el ámbito-donde se debate la violencia como cuestión que atañe a la estética; eso no quiere decir que se intente "estetizar" el horror, sino que, por el contrario, se le da al arte una función central como el eje que permite pensar y recordar lo político.

${ }^{16}$ Es sintomático en este sentido el capítulo "Tatuajes" de la tercera sección en el que el narrador-autor latinoamericano del presente se adormece en la biblioteca mirando los grabados de De Bry y sueña o imagina una escena en la que su mirada le es devuelta por "su doble", cautivo en una ceremonia de canibalismo: "Una de ellas tiene el garrote y sigue retocando los dibujos [...] Son pequeñas y extrañas geometrías que soy incapaz de descifrar. [...] Es allí donde debe estar la víctima, supongo. Me aproximo y entonces lo veo. Está amarrado a un árbol. Es blanco. Está desnudo. Es flaco y alto. Y me mira con mis ojos aterrados" (237). Obsérvese la distancia que media de la identificación de Le Moyne en la primera sección a la mirada "aterrada" y ajena de esta escena en la última parte. 
En los dos autores, el espacio de encuentro de ambas prácticas - política y estéticase da en el cruce de lo pictórico y la escritura; en Padura, la presencia de la imagen posibilita una especie de balance entre arte y política, hay un nexo que actúa a manera de vaso comunicante y que no permite que el texto se incline exclusivamente hacia lo referencial; en Montoya, la imagen es el centro mismo del pensar político. Puede postularse entonces con Rancière que la creación estética pertenece de por sí al campo político, y recíprocamente lo político se juega en las formas estéticas. ${ }^{17}$ Es que la capacidad del arte para construir un imaginario es política; en el vínculo con la pintura, tan importante como la obra que está delante de los ojos es el hecho de desplegar ante ella la memoria o la imaginación, construir asociaciones, producir alternativas de sentido. Lo político se desplaza entonces de la palabra a la imagen y viceversa, una parece iluminar la otra. Funcionan en una relación metonímica, en un espacio en que se encuentran y completan diversos conceptos y opuestos: auténtico, falso, libertad, compromiso, ilusión, verdad. El desplazamiento a la pintura permite "decir de otra manera", con otro lenguaje, con otro código; Padura, en especial, de algún modo atenúa y complejiza los pasajes en que el mensaje político se hace peligrosamente explícito en términos de lo deseable para su proyecto literario. Si pensamos que lo político suele ser leído como una salida a la referencia externa, estas novelas abren, gracias a esa presencia de la imagen como catalizadora de sentidos, la posibilidad de leerlas dentro de la lógica de lo estético, en una exploración de diferentes discursos, es decir, como arte, como literatura.

\section{BIBLIOGRAFÍA}

Amar Sánchez, Ana María. "El arte de la política/ la política del arte: Semprún y Padura ante el asesinato de Trotsky". Cuadernos de Literatura XVIII/35 (junio 2014): 247-58.

Badiou, Alain. Pequeño manual de inestética. Buenos Aires: Prometeo, 2009.

Bozal, Veleriano. Johannes Vermeer de Delft. Madrid: Tf Editores, 2003.

Donoso Macaya, Ángeles. "Estética, política y el posible territorio de la ficción en 2666 de Roberto Bolaño”. Revista Hispánica Moderna 62/2 (Dec. 2009): 125-42. Fernández Pérez, Carlos. "Pintura y memoria en las novelas de Semprun". Revista Historia, Antropología y Fuentes Orales 46 (2011): 47-59.

Fusillo, Massimo. Estética de la literatura. Madrid: La balsa de la Medusa, 2012.

17 "La relación entre estética y política es entonces, más concretamente, la relación entre esta estética de la política y la 'política de la estética', es decir la manera en que las prácticas y las formas de visibilidad del arte intervienen en la división de los sensible y en su reconfiguración" (Ranière, Sobre políticas 19).

111 Revista Iberoamericana, Vol. LXXXV, Núm. 269, Octubre-Diciembre 2019, 1189-1204 
Hammerschmidt, Claudia. "La escritura como marca y máscara del significante ausente: Leonardo Padura y la visible ausencia de Guillermo Cabrera Infante". Hispanic Review 3 (Summer 2014): 359-76.

Jimenez, Marc. Fragments d'un discours esthétique. París: Klincksieck, 2014.

Montoya, Pablo. Tríptico de la infamia. Bogotá: Penguin Random House, 2014.

Nicoladzé, Françoise. "Jorge Semprún. Conquista y conciencia identitaria”. Jorge

Semprún o las espirales de la memoria. Xavier Pla, ed. Kasel: Reichenberger, 2010. 140-53.

Padura, Leonardo. Herejes. Buenos Aires: Tusquets. 2013. El hombre que amaba a los perros. Barcelona: Tusquets, 2011. Paisaje de otoño. México: Tusquets, 1998. "La puerta de Alcalá". La puerta de Alcalá y otras cacerías. San Juan: Ediciones Callejón, 2000. 13-41.

Rancière, Jacques. Aisthesis. Escenas del régimen estético del arte. Buenos Aires: Manantial, 2013. El destino de las imágenes. Buenos Aires: Prometeo, 2011. El malestar en la estética. Buenos Aires: Capital Intelectual, 2001. "Las paradojas del arte político". El espectador emancipado. Buenos Aires: Manantial, 2010. 53-84. Sobre políticas estéticas. Barcelona: Universitat Autonoma, 2005.

Richard, Nelly, ed. Políticas y estéticas de la memoria. Santiago de Chile: Cuarto Propio, 2000.

Semprún, Jorge. La segunda muerte de Ramón Mercader. Caracas: Tiempo Nuevo, 1970. Valdés, Adriana, ed. La política de las imágenes. Santiago de Chile: Metales Pesados, 2008.

Palabras clave: política - estética - imagen - pintura - escritura

Recibido: $\quad$ agosto 2016

Aceptado: $\quad$ mayo 2017 